\title{
THE ANTICOAGULANT EFFECTS IN RABBITS AND MAN OF THE INTRAVENOUS INJECTION OF SALTS OF THE RARE EARTHS
}

\author{
By SAMUEL B. BEASER, ARNOLD SEGEL, AND LEROY VANDAM \\ (From the Departments of Medicine and Surgery of the Beth Israel Hospital and Harvard \\ Medical School, Boston)
}

(Received for publication February 20, 1942)

The recent interest in the anticoagulant action of heparin has led us to seek a substance which might be similar in action but less expensive and simpler to administer. The anticoagulant effect of various rare earths given intravenously has been studied in lower animals $(1,2,3)$. As far back as 1920, Esnault and Brou (4), and Grenet and Drouin (5) injected rare earths in 40 to 100 mgm. doses intravenously into human subjects, as therapeutic agents in tuberculosis. More recently, Dyckerhoff and Goossens (6) found that neodymium salts injected intravenously prolonged (considerably) the coagulation time of the blood of dogs and man. These authors gave some 30 injections to human subjects, the total dosage of neodymium salt varying from 250 to $500 \mathrm{mgm}$. The anticoagulant action persisted for as long as 6 hours after a single injection, and no ill effects were noted. No anticoagulant effects resulted from the oral or subcutaneous administration of neodymium.

The need for a cheaper and more easily administered anticoagulating agent than heparin, led us to study the anticoagulant properties of rare earths. The experimental data which we obtained on animals justified an attempt to observe the effects of these substances in man. Our experience, which does not support the claims of Dyckerhoff and Goossens that they are harmless to man, is the subject of this report.

I. Preparation of salts of rare earths for intravenous injection: Neodymium nitrate was dissolved in distilled water or 0.4 per cent saline to a concentration of 0.8 to 2.0 per cent. Neodymium, acetate was prepared as follows: To a solution of neodymium nitrate an excess of concentrated $\mathrm{NH}_{4} \mathrm{OH}$ was added, precipitating the bluewhite finely divided hydroxide. This was dissolved in concentrated acetic acid, and the solution evaporated to the gummy neodymium acetate which dissolved readily in distilled water to make 1 to 2 per cent solutions. The neodymium lactate was similarly prepared by adding concentrated lactic acid to dissolve the hydroxide and dilute $\mathrm{NaOH}$ or $\mathrm{NaHCO}_{3}$ was added to make the solution just pink to phenol red. The resulting solution was filtered before use and diluted to a 1 to 2 per cent solution. All the solutions were autoclaved just before use.

II. Methods of investigation: The coagulation time of whole blood and plasma was determined by the Lee and White method (7). Serum neodymium was determined as follows: Since neodymium oxalate is of the same low order of solubility as calcium oxalate, the method of Clark and Collip (8) for the determination of calcium could be adapted to our purposes. This method precipitates the oxalate-insoluble salts of serum (usually only calcium, but after injection of neodymium, both calcium and neodymium) and titrates with $0.1 \mathrm{~N} \mathrm{KMnO}_{4}$ to an accuracy of $0.1 \mathrm{mgm}$. in a total of about $10 \mathrm{mgm}$. calcium per 100 cc. of serum. In our patients, neodymium concentration is determined as the difference between the "blood calcium" before and during the experiment. Urine neodymium was determined by precipitating all of the insoluble oxalates from an aliquot part of a 24-hour specimen: After separating and washing the precipitate, it was ignited (oxidizing the oxalate), redissolved in nitric acid, and neutralized by excess $\mathrm{NH}_{4} \mathrm{OH}$. The neodymium hydroxide in contrast to the calcium hydroxide is insoluble. Plasma hemoglobin was determined by the benzidine method as previously used in this hospital (9). Red cell fragility was performed by a quantitative method (10). Urine albumin was determined as the urine total protein by a gravimetric, trichloracetic precipitation test. ${ }^{1}$

\section{RESULTS}

\section{In vitro studies of the effect of neodymium on rabbit plasma}

Oxalated normal rabbit plasma, recalcified with an excess of a 0.28 per cent solution of $\mathrm{CaCl}_{2}$, was found to have a coagulation time of $5 \mathrm{~min}$ utes. Addition of $0.1 \mathrm{cc}$. of distilled water to $0.1 \mathrm{cc}$. of such plasma resulted in a coagulation time of $43 / 4$ minutes; when, however, $0.1 \mathrm{cc}$. of solutions of neodymium nitrate in distilled water of 0.003 per cent, or greater concentration, was added to $0.1 \mathrm{cc}$. of such recalcified plasma, the coagulation time was prolonged (Table I).

1 We are indebted to Doctors M. D. Altschule and D. R. Gilligan for performing the plasma hemoglobin, red cell fragility, and urine albumin determinations recorded in these experiments. 
TABLE I

The effect of 0.1 cc. of $N d\left(N O_{3}\right)_{3}$ solution on the coagulation time of 0.1 cc. of recalcified oxalated rabbit's plasma

\begin{tabular}{cc}
\hline \hline Concentration of $\mathrm{Nd}\left(\mathrm{NO}_{3}\right)_{3}$ & Plasma coagulation time \\
\hline$m g m$. per $0.1 \mathrm{cc}$. & minutes \\
0.003 & 4.25 \\
0.004 & 6.0 \\
0.006 & 4.75 \\
0.008 & 5.5 \\
0.013 & 7.5 \\
0.017 & 8.0 \\
0.025 & No coagulation resulted but \\
0.033 & fine particles appeared \\
0.050 & along sides of test tube after \\
& a considerable interval.
\end{tabular}

\section{In vitro studies of the effect of neodymium on} human plasma

Oxalated recalcified normal human plasma was found to have a coagulation time of $5 \frac{1}{2}$ minutes. When $0.1 \mathrm{cc}$. of distilled water was added to 0.1 cc. of such plasma the coagulation time was 6 minutes; when, however, $0.1 \mathrm{cc}$. of solutions of neodymium nitrate in distilled water of 0.003 per cent, or greater concentration, was added to $0.1 \mathrm{cc}$. of such plasma, the coagulation time was prolonged (Table II).

TABLE II

The effect of $0.1 \mathrm{cc}$. of $\mathrm{Nd}\left(\mathrm{NO}_{3}\right)_{3}$ solution on the coagulation time of 0.1 cc. of recalcified oxalated human plasma

\begin{tabular}{cc}
\hline \hline Concentration of $\mathrm{Nd}\left(\mathrm{NO}_{3}\right)_{3}$ & Plasma coagulation time \\
\hline mgm. per $0.1 \mathrm{cc}$. & minutes \\
0.003 & 6.0 \\
0.004 & 6.5 \\
0.006 & 8.25 \\
0.008 & 9.5 \\
0.013 & 21 \\
0.017 & 24 \\
0.025 & \\
0.033 & No coagulation resulted but \\
0.050 & fine particles appeared \\
& along sides of test tube. \\
\hline
\end{tabular}

\section{In vivo studies in the rabbit}

Several groups of rabbits were given various amounts of a 5 per cent solution of neodymium nitrate intravenously, all the animals in a given group receiving the same amount; blood samples, secured from the heart by a long needle and syringe previously rinsed in normal saline, were taken from one or more rabbits at varying intervals up to 6 hours after injection. ${ }^{2}$

2 This procedure was necessitated by the fact that in the presence of a prolonged coagulation time, cardiac
The average coagulation time after each dose (Figure 1) was increased, being greatest in the first hour or two after injection, following which it declined. The coagulation time and the duration of delayed coagulability varied with the dose injected. When the clotting time was prolonged beyond 3 to 5 hours, the end point was indefinite and a true clot did not form for days; instead, fine masses of coagulum, less than $1 \mathrm{~mm}$. in diameter, were deposited on the sides of the tube.

Toxicity. Since the solutions seemed to cause restlessness in rabbits, an effort was made to complete the injection as rapidly as possible. In later experiments the rate of injection was decreased to $1 \mathrm{cc}$. per minute. During rapid injection of smaller doses or slower injection of large doses, whining or restlessness occurred and were followed by death before the end of injection. In smaller dosage some rabbits developed

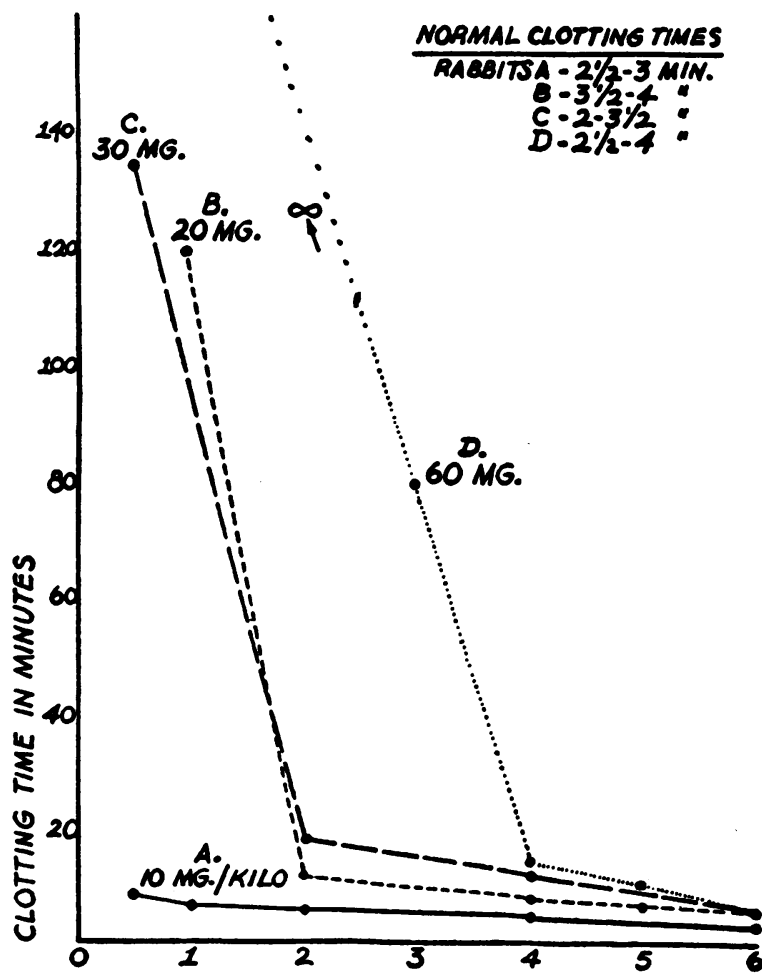

TIME IN HOURS AFTER NEOOYMIUM INJECTION

Fig. 1. The Anticongulant Effects of Varying Doses of NeOdymium in Rabits

puncture caused fatal hemopericardium so often that more than two successive samples from a given rabbit were usually not procurable. 
opisthotonos and thrashed their feet about, usually dying within 30 minutes. Others appeared limp and stunned, recovering partially after 10 to 30 minutes, only to die 24 to 48 hours later. One rabbit which received $80 \mathrm{mgm} .{ }^{3}$ slowly injected, showed flaccid paralysis of the legs 3 days later. The dosage producing these toxic effects varied considerably, as little as 50 to $80 \mathrm{mgm}$. causing immediate death if injected rapidly. Some rabbits survived after 80 to $120 \mathrm{mgm}$. doses, while others lived for as long as 24 to 48 hours after slowly injected doses as high as $200 \mathrm{mgm}$.

The irritating effect of neodymium nitrate solution resulted in phlebitis within 24 hours after injection, with edema and subsequent necrosis of the rabbit's ear. When the clotting time was markedly prolonged, the site of injection bled persistently and marked anemia occurred.

The toxicity of sublethal doses, repeated over an extended period of time, was studied in 2 rabbits.

One rabbit received $80 \mathrm{mgm}$. of $\mathrm{Nd}\left(\mathrm{NO}_{3}\right)_{3}$ daily for 2 days. Two days after the second injection, the animal had a flaccid paralysis of all 4 limbs and was sacrificed.

At autopsy, the only gross findings were a few white millet-seed sized firm nodules in the liver. On microscopic examination, the liver showed small round cell infiltrations about the periphery of the lobules; the lungs showed a few small areas of atelectasis about bronchioles and a few patchy areas of pneumonitis. The brain and remaining organs were essentially normal.

A second rabbit received $840 \mathrm{mgm}$. of $\mathrm{Nd}\left(\mathrm{NO}_{8}\right)_{3}$ in doses of 50 to $100 \mathrm{mgm}$. daily, over a period of 12 days, with no untoward manifestations. It was sacrificed on the 12th day. Autopsy was negative.

\section{In vivo studies in man}

Having established a minimum lethal dose in rabbits, having confirmed the innocuousness of small anticoagulant doses in animals as previously reported, and having found no reference to severe untoward effects in man, we decided cautiously to administer neodymium to humans. Accordingly, 18 patients were given intravenous doses of neodymium far below the expected levels of toxicity as determined in animals. These patients were mainly in the first postoperative week of various surgical procedures, so chosen because of the oc-

3 All doses referred to in this paper are in terms of the weight of the rare earth salt per kilogram. casional occurrence of phlebothrombosis in this period, and because of the recently proposed use of heparin routinely as prophylaxis against this condition.

An anticoagulant effect was produced by single intravenous doses varying from 4.5 to $12.5 \mathrm{mgm}$. of neodymium salt per kilogram of body weight (Table III).

TABLE III

The anticoagulant effect of single injections of neodymium acetate in man

\begin{tabular}{|c|c|c|c|c|c|}
\hline $\begin{array}{l}\text { Subject } \\
\text { number }\end{array}$ & Total & Dose & $\begin{array}{c}\text { Clotting } \\
\text { time before } \\
\text { injection }\end{array}$ & $\begin{array}{c}\text { Interval } \\
\text { after } \\
\text { injection }\end{array}$ & $\begin{array}{l}\text { Clotting } \\
\text { time after } \\
\text { injection }\end{array}$ \\
\hline & mgm. & $\underset{\mathrm{kgm} .}{\operatorname{mgm} . \text { per }}$ & minutes & minutes & minutes \\
\hline $\begin{array}{l}1 \\
2 \\
3 \\
4 \\
5 \\
6 \\
7 \\
8 \\
9\end{array}$ & $\begin{array}{r}200 \\
400 \\
400 \\
600 \\
640 \\
1000 \\
800 \\
250 \\
622\end{array}$ & $\begin{array}{c}3 \\
6 \\
7 \\
7.5 \\
8 \\
12.5 \\
9.75 \\
4.5 \\
10\end{array}$ & $\begin{array}{l}10 \\
11 \\
12 \\
11 \\
11.5 \\
12 \\
15 \\
16 \\
12\end{array}$ & $\begin{array}{l}15 \\
20 \\
20 \\
20 \\
20 \\
24 \\
20 \\
67 \\
67\end{array}$ & $\begin{array}{l}12.5 \\
20 \\
11 \\
16 \\
15 \\
42 \\
20 \\
24 \\
20\end{array}$ \\
\hline
\end{tabular}

Doses of more than $10 \mathrm{mgm}$. produced an anticoagulant effect which reached a peak in $1 / 2$ to $11 / 2$ hours, followed by a decline. Small additional doses of neodymium given during the phase of decreasing clotting time caused a substantial increase in clotting time (Figure 2). One dose of $18 \mathrm{mgm}$. resulted in an indefinitely prolonged clotting time, $3 \frac{1}{2}$ hours after injection (Figure 3 ). About 5 hours after injection when the clotting time was 50 minutes, gross hematuria was noted.

Toxicity. Because neodymium nitrate solution caused thrombophlebitis at the site of injection in man, the acetate and lactate salts of neodymium were substituted. The latter salts produced a painless thrombosis of the injected vein after 24 to 48 hours in about a fourth of the cases, when total doses of $300 \mathrm{mgm}$. and over were given. After 10 of 17 injections, fever ranging as high as $101^{\circ}$ occurred 3 to 18 hours following administration. Headache, sweating, muscle and abdominal pains, nausea, and vomiting also occurred. These symptoms were unrelated to the degree of anticoagulant effect, thrombophlebitis, or hemoglobinemia (see below) and were considered to be toxic manifestations of the drug. Moreover, no one patient had all the aforementioned side effects and several patients had none. 


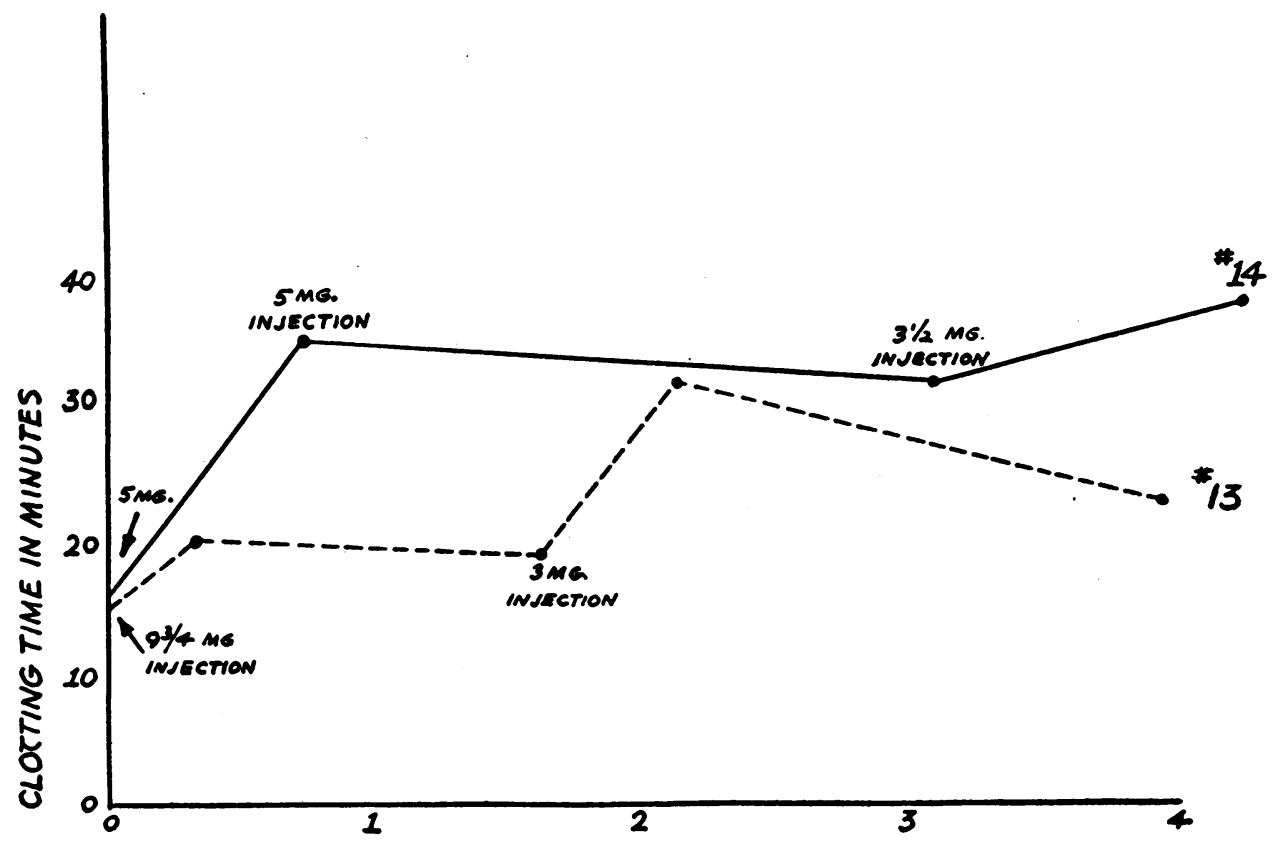

HOURS AFTER FIRST INJECTION OF NEODYMIUM LACTATE.

Fig. 2. The Anticongulant Effect of Repeated Doses of Neodymium in Man

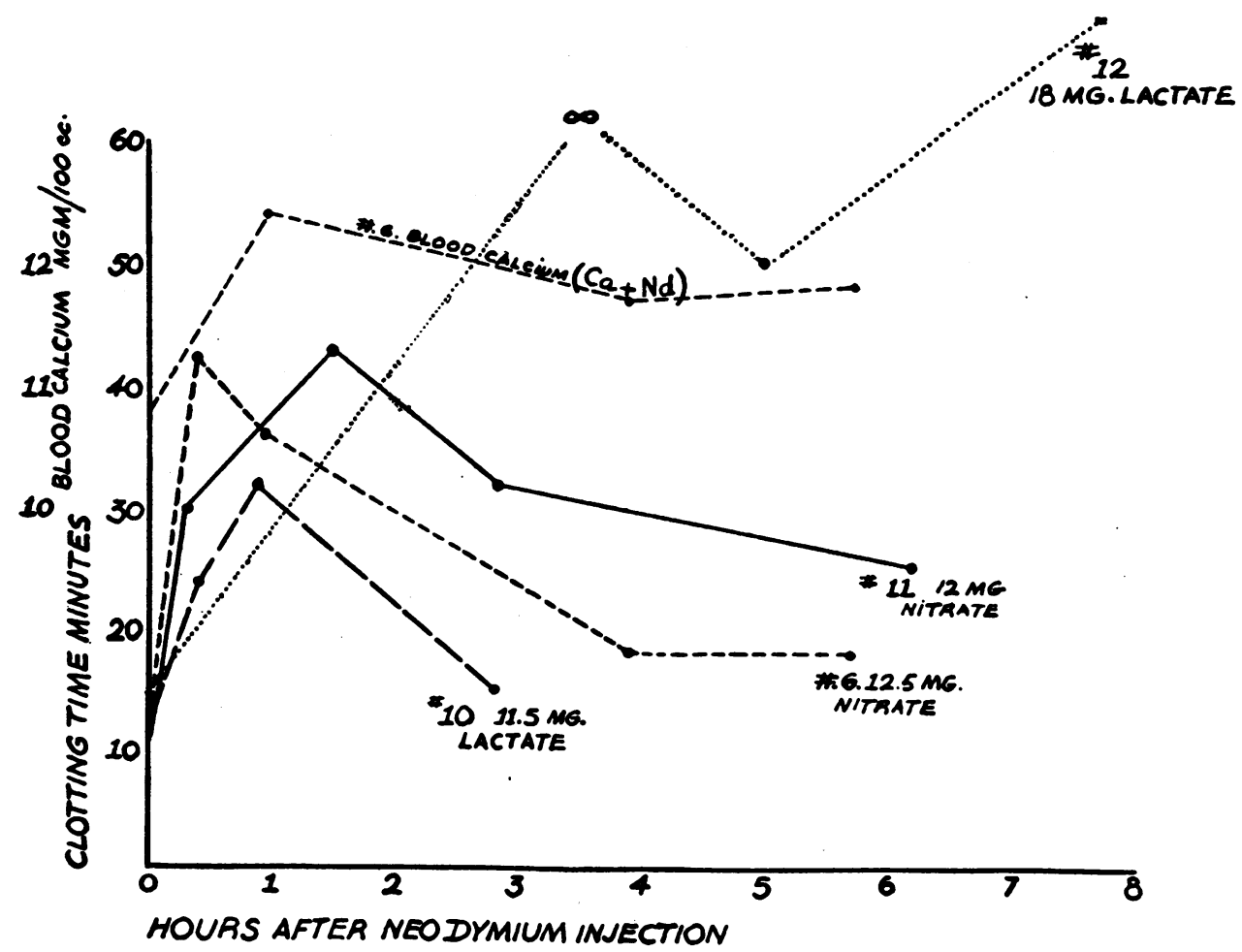

Fig. 3. The Anticongulant Effect of Varying Doses of Neodymium in Man 
Other rare earths, lanthanum acetate and cerium acetate, were given in doses varying from 1.6 to $5 \mathrm{mgm}$. Because similar but more severe toxic symptoms resulted even before anticoagulant doses were reached, further use of these drugs was not attempted.

An attempt was made to avoid toxic reactions by altering the mode of administration, as suggested by Greenbaum and Aye (11) who noted a reduction in the toxicity of thorium salts in rabbits after dissolving the salts in 50 per cent sucrose solution. Accordingly, one patient was given 9.5 mgm. of neodymium in a 50 per cent sucrose solution but toxic symptoms were not prevented.

Two patients were given daily doses increasing from 1 to $6 \mathrm{mgm}$., over a period of a week in an attempt to obviate toxic effects, as suggested by Dyckerhoff and Goossens (6). There were no untoward symptoms, but hemoglobinemia resulted.

Hemoglobinuria occurred as a toxic manifestation after injection of neodymium in man. Of 10 patients who received single doses from 1.2 to 1.8 mgm., 5 showed plasma hemoglobin values above the normal of $9 \mathrm{mgm}$. per cent, for 1 to 3 hours after injection. In 3 patients, plasma hemoglobin levels suggesting the breakdown of 10 to $20 \mathrm{cc}$. of blood were found. In another instance, the plasma hemoglobin was $17 \mathrm{mgm}$. per $100 \mathrm{cc}$., 24 hours after injection of neodymium; it was not possible to estimate the degree of hemolysis in this instance. In one experiment, the patient had a moderate headache the morning after receiving an initial dose of $11.5 \mathrm{mgm}$. An additional dose of $14 \mathrm{mgm}$. was then given; 1 hour later the clotting time was over 8 hours and the plasma was normal in color. Two hours after injection the patient voided a dark red urine and complained of severe abdominal pain which recurred several times during the next 24 hours. The body temperature did not rise above $99.8^{\circ}$. The red urine persisted for 2 days and on the third day, when the urine was of normal color though still positive to benzidine, the blood showed a plasma hemoglobin of $143 \mathrm{mgm}$. per $100 \mathrm{cc}$., and a bilirubin of $1.1 \mathrm{mgm}$. per $100 \mathrm{cc}$. The fragility of the red cells at this time was normal and the total blood hemoglobin and erythrocyte count were the same as before injection. The plasma hemoglobin reached normal 5 days after the onset of hemoglobinemia. Probably several hundred cc. of blood had been hemolyzed.

Another patient who showed hemoglobinuria had received progressively increasing doses of neodymium lactate over a period of a week (Figure 4). The last dose resulted in a definite anticoagulant effect; no toxic symptoms occurred. A light mahogany colored urine was voided on the morning of the seventh day; this specimen showed strongly positive benzidine and guaiac tests. There were granular casts and 1 to 4 red blood cells and white blood cells in centrifuged specimens of the darkest urines. The casts contained large granules which turned black on the application of $\left(\mathrm{NH}_{4}\right)_{2} \mathrm{~S}$ solution indicating the presence of hemoglobin pigment. No anemia resulted from this attack of intravascular hemolysis. There was no clinical jaundice and the plasma bilirubin increased only slightly.

Hemolysis was not produced in vitro when $1 \mathrm{mgm}$. of neodymium per cc. was added to human blood which was allowed to stand at room temperature and at $37.5^{\circ} \mathrm{C}$. for as long as 2 hours; nor was it produced in one dog given $50 \mathrm{mgm}$. of neodymium nitrate per kilo.

\section{DISCUSSION}

The anticoagulant effect of neodymium nitrate in rabbits was found to be similar to that reported in dogs (3). The minimal effective dose was about $10 \mathrm{mgm}$. per $\mathrm{kgm}$. of body weight and the lethal dose was $80 \mathrm{mgm}$. or more.

The anticoagulant effects of neodymium salts in man show a close resemblance to those in rabbits. When either rabbit or human whole blood was tested, 1.25 to $2.0 \mathrm{mgm}$. of neodymium salt were required to prevent $1 \mathrm{cc}$. of blood from clotting indefinitely. Raising the dose increases both the clotting time and the duration of the effect. The minimal effective dose in man varies from 5 to 8 mgm. per kgm. The increase in coagulation time reaches a peak within an hour or so, and then starts to decrease; the clotting time can be prevented from returning to normal by administration of successive smaller doses. When the dose is increased above $14 \mathrm{mgm}$., the blood is rendered

4 This may be used roughly as an index of the normal functional state of this patient's liver (after receiving $20 \mathrm{mgm}$. per $\mathrm{kgm}$. of neodymium), in view of its ability to handle blood pigments released intravascularly. 


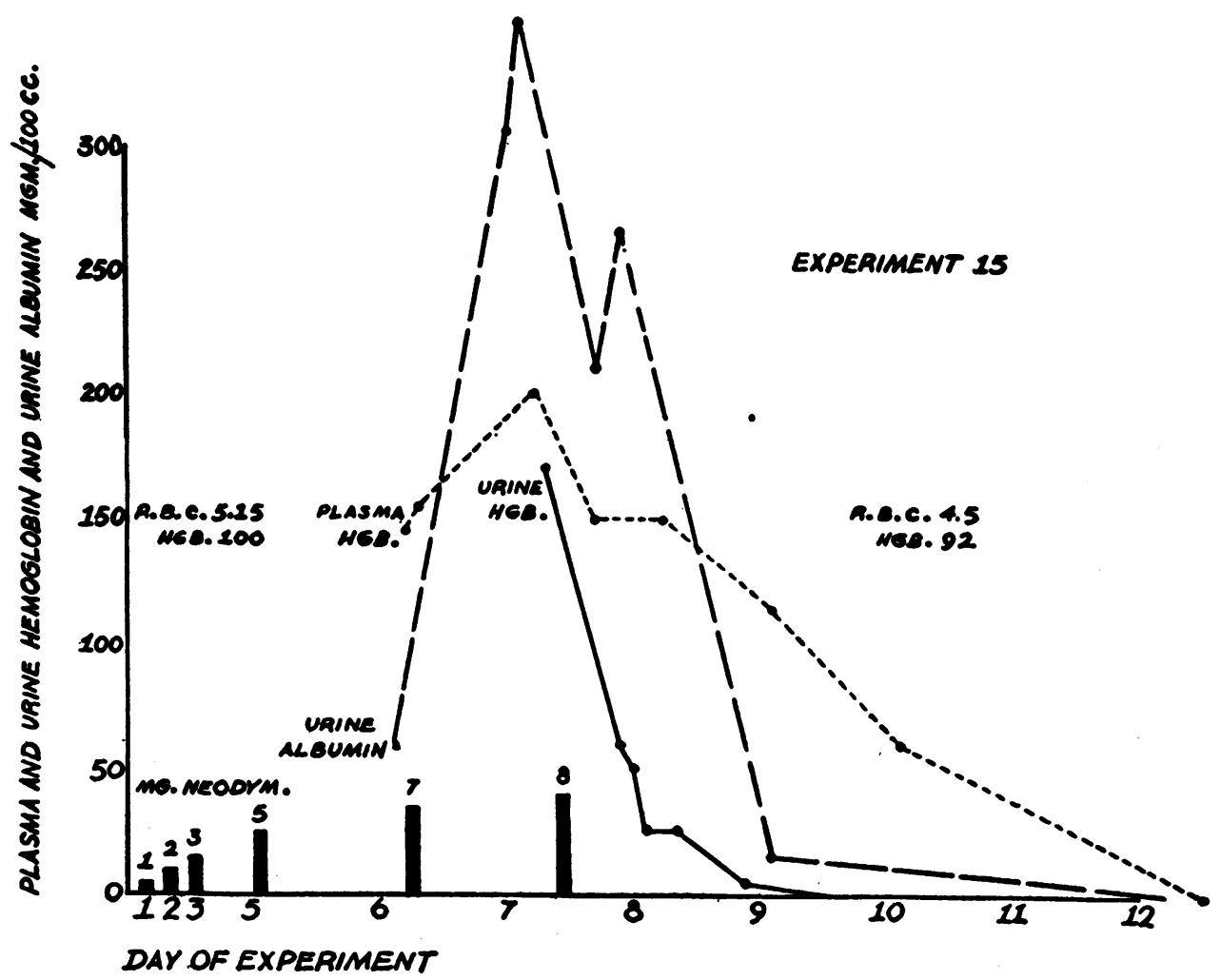

Fig. 4. The Course of Hemoglobinemia and Hemoglobinuria in Man Following NEODYMIUM

uncoagulable. As an example of the range of values involved, a single dose of $12 \mathrm{mgm}$. increased the clotting time to 2 to 4 times normal for a period of over 6 hours.

All of the rare earths are anticoagulant substances (3). The mode of action is not completely understood but is independent of the anions used (12). They do not act by interfering with the coagulant effect of calcium (13). Glazko and Greenberg, who studied the activity of thorium salts in vitro, concluded that, "the inhibiting action of polyvalent cations was found to be due to their effect on fibrinogen" (14), in contrast to polyvalent anions and heparin which act on prothrombin.

The problem is made more complicated by the fact that the dose required to render blood uncoagulable indefinitely in dogs (3) is greater in vitro than in vivo. This ratio was found to be about 10 to 1 in man. ${ }^{5}$ Moreover, the action of

\footnotetext{
5 In vitro, about 125 to $200 \mathrm{mgm}$. is required per 100 cc. of blood. By contrast, a patient with approximately
}

the drug in vivo requires 30 to 120 minutes to reach a maximum, whereas in vitro the effect is immediate.

It has been shown that the concentration of either prothrombin (15) or fibrinogen (16) in plasma must be reduced by. fully 80 per cent before clotting time is measurably prolonged. Moreover, after the prothrombin concentration has been reduced to this critical level, any further reduction causes a rapidly increasing clotting time (15). This resembles the sequence of events which appears when neodymium inhibits the activity of fibrinogen in blood. Study of the action of neodymium both in animals and man shows that after the minimal dose necessary to prolong the clotting time has been given, further administration of relatively small doses causes rapid prolongation of the clotting time.

a $6000 \mathrm{cc}$. blood volume required $1000 \mathrm{mgm}$. of neodymium lactate to render blood withdrawn one hour after injection uncoagulable indefinitely. This is equivalent to 17 mgm. per 100 cc. 
Studies of the blood level of neodymium show that the element is still present in considerable amount in the blood during the stage of decline in the anticoagulant effect. Repeated urinalyses showed that in our experiments it is not excreted by the human kidney. Available evidence suggests that it is removed by the reticulo-endothelial system of the liver and spleen (6).

Local thrombophlebitis has been reported to occur in dogs (17) after injection of rare earth chlorides. Similarly thrombophlebitis was observed by us in man after injection of neodymium nitrate but a change to the less acid salts (lactate or acetate) resulted only in bland thrombosis.

Hemoglobinemia was unexpected because it had not been previously noted in experimental animals or man. The cause of the intravascular hemolysis has not been determined; it did not occur when neodymium was added to the blood in vitro. Although hemolysis occurs after a latent period of one or two hours, corresponding to the time of maximum anticoagulant effect, we have encountered it after very little change in blood clotting time. In one patient, the fragility of the red cells in hypotonic saline solution was normal 4 hours after injection, when the anticoagulant activity was greatest, and when the plasma hemoglobin was $38 \mathrm{mgm}$. per cent. The volume of red cells destroyed to produce the hemoglobinemia observed in these studies was not great enough to cause anemia or detectable jaundice. Hemoglobinemia persisting for as long as $\mathbf{5}$ days in one case, demonstrated a continuing process of hemolysis, since after a single intravenous injection of 1.3 to 16 grams of hemoglobin only a few hours are required to clear the plasma of hemoglobin (9). Signs of temporary renal irritation; namely albuminuria and the excretion of casts, persisted during the period of hemoglobinuria and for a few days thereafter.

Hematuria was noted in one patient who received the highest dose of neodymium (18 $\mathrm{mgm}$. per kgm.) and whose blood was rendered uncoagulable for a brief period (No. 12, Figure 3 ). We consider this phenomenon to be related to the lengthened coagulation time rather than the anticoagulant, for both internal and external hemorrhage have been reported when blood clotting time is greatly prolonged in heparin administra- tion (18), in sweetclover disease of cattle (19), and in hemorrhagic disease of chicks (20). Accordingly this complication was not considered to be a toxic manifestation peculiar to neodymium itself.

The ability of the livers of the 2 patients with hemoglobinuria to handle the hemoglobin released into the circulation with so little elevation of blood bilirubin is comparable with that of normal livers, and would indicate that while the drug may be stored in the liver, it does not impair the function of this organ appreciably.

\section{SUMMARY}

Neodymium, lanthanum, and cerium, administered intravenously, in appropriate dosage in rabbits and men, increase the clotting time of blood to the point of incoagulability. This effect persists in a diminishing degree for as long as 8 hours after injection. Toxic manifestations, such as chills, fever, muscle pains, abdominal cramps, hemoglobinemia and hemoglobinuria, result from the use of these rare earth metals. These effects render inexpedient the administration of these drugs as anticoagulants in man.

\section{BIBLIOGRAPHY}

1. Heffter, A., and Heubner, W., Handbuch der experimentellen Pharmakologie. Volume 3, Section 3, J. Springer, Berlin, 1930.

2. Guidi, G., Contributo alla farmacologia delle terre rare; il neodimio. Arch. internat. de pharmacodyn. et de thérapie, 1930, 37, 305.

3. Vincke, E., and Oelkers, H. A., Zur Pharmakologie der seltenen Erden; Wirkung auf die Blutgerinnung. Arch. f. Exper. Path. u. Pharmakol., 1937, 187, 594.

4. Esnault, M., and Brou, M., Resultats du Traitement de Quelques Cas de Tuberculose Pulmonaire Chronique par les Sulfates de Terres Rares. Bull. et mém. Soc. méd. d. hôp. de Par., 1920, 44, 606.

5. Grenet, $H$., and Drouin, $H$., Les Sels de Terres de la Serie du Cerium dans le Traitement de la Tuberculose Pulmonaire Chronique. Gaz. d. hôp., 1920, 93, 789.

6. Dyckerhoff, H., and Goossens, N., Uber die thromboseverhütende Wirkung des Neodyms (Neodympräparat "Auer 144"). Ztschr. f. d. ges. exper. Med., 1939, 106, 181.

7. Stitt, E. R., Clough, P. W., and Clough, M. C., Practical Bacteriology, Haematology and Animal Parasitology. P. Blakiston's Son \& Co., Philadelphia, 1937, p. 324. 
8. Hawk, P. B., and Bergeim, O., Practical Physiological Chemistry. P. Blakiston's Son and Co., Philadelphia, 1927, p. 408.

9. Gilligan, D. R., Altschule, M. D., and Katersky, E. M., Studies of hemoglobinemia and hemoglobinuria produced in man by intravenous injection of hemoglobin solutions. J. Clin. Invest., 1941, 20, 177.

10. Hunter, F. T., A photoelectric method for the quantitative determination of erythrocyte fragility. J. Clin. Invest., 1940, 19, 691.

11. Greenbaum, F. R., and Aye, C. E., The pharmacological behavior of sodium thorium tartrate and its roentgen diagnostic value. Am. J. Roentgenol., 1941, 45, 265.

12. Fischler, F., Uber experimentelle Beeinflussung der Leberfunktionen und der Anatomischen Leberstruktur durch Einwirkung seltener Erden. Arch. f. Exper. Path. u. Pharmakol., 1938, 189, 4.

13. Dyckerhoff, H., von Behm, W., Goossens, N., and Miehler, $H$., Uber die Gerinnung des Blutes. Biochem. Ztschr., 1936, 288, 271.

14. Glazko, A. J., and Greenberg, D. M., The mechanism of the inhibiting effect of electrolytes and heparin on blood coagulation. Am. J. Physiol., 1940, 128, 399.
15. Quick, A. J., The coagulation defect in sweet clover disease and in the hemorrhagic chick disease of dietary origin. Am. J. Physiol., 1937, 118, 260.

16. Nygaard, K. K., Hemorrhagic Diseases: PhotoElectric Study of Blood Coagulability. C. V. Mosby Co., St. Louis, 1941, p. 139.

17. Oelkers, H. A., and Vincke, E., Zur Pharmakologie der seltenen Erden; Wirkung auf das Blutbild. Arch. f. Exper. Path. u. Pharmakol., 1938, 188, 53.

18. (a) Witts, L. J., Heparin in subacute bacterial endocarditis. Brit. M. J., 1940, 1, 484.

(b) Ershler, I. L., and Blaisdell, I. H., Massive hematuria following use of heparin in cavernous sinus thrombosis. J. A. M. A., 1941, 117, 927.

(c) de Takats, G., Heparin. J. A. M. A., 1941, 117, 1378.

(d) Ershler, I. L., and Blaisdell, I. H., Heparin for prolonged coagulation time. J. A. M. A., 1941, 117, 2095.

19. Schofield, F. W., Damaged sweet clover: The cause of a new disease in cattle simulating hemorrhagic septicemia and blackleg. J. Am. Vet. M. A., 1924, 64, 553.

20. Holst, W. F., and Halbrook, E. R., A "scurvy-like" disease in chicks. Science, 1933, 77, 354. 